\section{Kinerja Perusahaan Perbankan Syariah Di Indonesia: \\ Pembiayaan Murabahah, Musyarakah, Ijarah}

Sharia Financing

and Banking

Performance

\section{1}

\author{
Muhammad Noor ${ }^{1}$, M. Sahib Saesar Anugrah ${ }^{2}$, Amrie Firmansyah $^{3}$ \\ 1,2,3 Jurusan Akuntansi, Politeknik Keuangan Negara STAN \\ Email: muhammadnoor.91@gmail.com¹, saesarsahib@gmail.com², \\ amrie@pknstan.ac.id ${ }^{3}$
}

SEPTEMBER 2020

Accepted:

NOVEMBER 2020

\begin{abstract}
Firm value is a reflection of market performance. Furthermore, firms can be observed by their operational performance. One of the essential aspects of operating performance is profitability. This study aims to analyze Murabahah, Musyarakah, and Ijarah on the firm performance on Sharia Bank. The firm performance consists of both operation performance, which is represented by profitability, and market performance, represented by firm value. This research employs the quantitative method. This research used secondary data from sharia bank monthly reports from 2018 to 2020 obtained from IDX. Using purposive sampling, the selected samples in this research has 84 observation. The hypothesis examination used in this research is multiple linear regression analysis of pooled data. This study finds that murabahah has a positive effect on profitability, musyarakah has a negative effect on profitability, ijarah does not affect profitability, murabahah, and musyarakah does not affect firm value. In contrast, ijarah has a negative effect on firm value.
\end{abstract}

Keywords: Murabahah, Musyarakah, Ijarah, Firm Performace.

\section{PENDAHULUAN}

Saham merupakan salah satu instrumen keuangan yang diperjualbelikan secara aktif di Bursa Efek Indonesia. Setiap perusahaan yang melantai di bursa selalu berusaha menjaga harga saham mereka tetap stabil, bahkan cenderung meningkat. Selain menampilkan kurva yang optimis, tingginya harga saham juga memberikan keuntungan lain bagi perusahaan. Tingginya harga saham, akan memperbesar setoran modal yang diterima perusahaan yang selanjutnya akan dapat dipergunakan untuk men-generate keuntungan yang lebih besar. Kendati demikian, harga saham tidak sepenuhnya berada di bawah kendali perusahaan itu sendiri. Ada berbagai macam faktor yang dapat mempengaruhi fluktuasi harga saham.

Harga saham yang tinggi mencerminkan besarnya minat investor dalam menanamkan modalnya di perusahaan. Dengan kata lain, harga saham melambangkan seberapa besar tingkat kepercayaan investor atas pengembalian yang akan diperoleh dari kinerja perusahaan di masa yang akan datang. Penurunan harga saham secara drastis atas satu emiten di bursa bukan suatu hal yang mustahil. Hal ini dapat terjadi ketika sejumlah besar investor secara serentak melakukan penarikan modal karena kehilangan kepercayaan terhadap perusahaan. Persepsi negatif investor seperti demikian belum lama ini terjadi pada salah satu perusahaan plat merah, PT Garuda Indonesia.

Skandal dan pemberitaan negatif yang berhembus dari PT Garuda Indonesia berimbas pada jatuhnya harga saham GIAA. Turunnya harga saham ini mencerminkan penurunan

\section{JIMKES}

Jurnal Ilmiah Manajemen Kesatuan Vol. 8 No. 3,2020 pp. $281-294$ ISSN $2337-7860$ E-ISSN $2721-169 \mathrm{X}$ 
Sharia's Financing and Banking

Performance

nilai perusahaan di mata investor. Padahal nilai perusahaan merupakan elemen penting yang dipertahankan sebuah perusahaan untuk menunjukkan tingkat keberhasilan perusahaan, dimana keberhasilan tersebut akan mempengaruhi kesejahteraan pemegang saham dan perusahaan itu sendiri. Nilai perusahaan juga dapat dilihat sebagai indikator keberhasilan sebuah perusahaan dalam aktivitasnya untuk mengelola dan mengoperasikan perusahaan (Perwitasari, 2019).

Nofrita (2013) menyebutkan bahwa nilai perusahaan merupakan persepsi investor terhadap perusahaan yang sering dikaitkan dengan harga saham. Harga saham yang tinggi mencerminkan nilai perusahaan yang tinggi. Harga ini mencerminkan sejauh mana investor menyetujui untuk membayar kepemilikan dengan mempertimbangkan keuntungan yang akan diraihnya.

Nilai perusahaan merupakan refleksi dari kinerja pasar. Kinerja ini merupakan suatu aspek penting bagi entitas sebagai hasil atas strategi yang dijalankan perusahaan. Di sisi lain, perusahaan juga dapat dinilai berdasarkan kinerja operasi. Salah satu aspek penting dalam kinerja operasi perusahaan adalah kemampuan menghasilkan keuntungan usaha atau tingkat profitabilitas.

Profitabilitas menjadi salah satu parameter penting dalam mengukur ketercapaian tujuan perusahaan. Profitabilitas merupakan ukuran kemampuan perusahaan dalam menghasilkan keuntungan dan mengukur tingkat efisiensi operasional dan efisiensi dalam menggunakan harta yang dimiliki. Selain itu, profitabilitas juga didefinisikan sebagai kemampuan perusahaan dalam menghasilkan laba selama periode tertentu yang dapat dihitung berdasarkan penjualan atau aktiva atau modal sendiri (Nofrita, 2013). Dari sini dapat dikatakan bahwa profitabilitas mengukur seberapa baik suatu perusahaan menggunakan sumber dayanya dalam menghasilkan laba dalam periode tertentu.

Tingkat profitabilitas perusahaan yang tinggi akan mencerminkan kinerja operasi yang baik. Hal ini dapat menjadi daya tarik bagi investor untuk turut menyertakan modal. Peningkatan laba akan memberikan sinyal positif kepada investor bahwa perusahaan tersebut profitable dan diharapkan mampu untuk memberikan kesejahteraan kepada pemegang saham melalui pengembalian saham yang tinggi (Hermuningsih, 2014). Banyaknya investor yang membeli saham perusahaan akan berpengaruh terhadap peningkatan nilai perusahaan.

Dari paparan di atas, dapat dilihat bahwa kinerja operasi memiliki keterkaitan dengan kinerja pasar perusahaan. Tingginya profitabilitas dan terjaganya kestabilan nilai perusahaan merupakan lampu hijau atas pertumbuhan usaha. Jika berkaca pada pasar di negeri ini, sejak dimulainya masa reformasi, terdapat beberapa sektor usaha yang pertumbuhannya berjalan secara konsisten. Salah satu sektor tersebut adalah dunia perbankan syariah.

Perbankan syariah memulai masa gemilangnya manakala Indonesia mengalami kondisi krisis moneter yang sangat memukul sektor keuangan nasional, terutama pada sektor perbankan. Krisis perbankan ini tidak terlepas dari krisis yang tengah terjadi di Asia dan Amerika serta diberlakukannya penyatuan mata uang Eropa sebagai proses dari ekonomi-politik. Rupiah yang terus terdepresiasi menjadi penyebab utama terguncangnya perbankan nasional.

Demi menjaga ketersediaan mata uang dan mempertahankan kepercayaan masyarakat, Bank Indonesia mengambil langkah untuk mencetak lebih banyak rupiah dan meningkatkan suku bunga bank. Sayangnya tindakan ini justru membuat lembaga keuangan Bank di Indonesia semakin terdesak. Bank tidak mampu menjaga likuiditasnya sebagai lembaga intermediasi, dimana pihak debitur yang dibebani bunga tinggi mengalami gagal bayar sedangkan di sisi lain bank tidak memiliki cukup uang untuk membayar bunga pada nasabah. Kondisi yang menyulitkan ini akhirnya mendorong ketidakpercayaan masyarakat yang berimbas pada penarikan dana secara besar-besaran.

Kolapsnya dunia perbankan Indonesia dikarenakan terjadinya negative spread, yaitu kerugian yang diakibatkan oleh tingkat suku bunga simpanan yang lebih tinggi dari suku bunga kredit. Meski begitu, ternyata negative spread tidak berpengaruh terhadap bank syariah. Hal ini dapat dilihat dari kondisi Bank Muamalat dan Bank Syariah Mandiri 
yang meskipun mengalami penurunan profit namun mampu bertahan di masa krisis tersebut. Ketahanan bank syariah tidak terlepas dari prinsip yang digunakan, yaitu prinsip bagi hasil, dimana produk yang ditawarkan tidak terpengaruh oleh fluktuasi BI rate.

Kendati demikian, eksistensi bank syariah kala itu masih belum mampu berbuat banyak pada industri perbankan secara makro. Hal ini dapat dipahami mengingat kontribusi bank syariah masih rendah. Berbeda dengan kondisi tersebut, di masa sekarang, apabila dilihat dari pasar global, berdasarkan peringkat dari Islamic Finance Development Indicator (IFDI), di tahun 2019 sektor keuangan syariah nasional mengalami peningkatan yang menggembirakan, dari yang semula berada di posisi sepuluh naik ke posisi empat dunia. Kenaikan ini ditunjang oleh perkembangan aset keuangan syariah sebesar lima persen menjadi USD 86 miliar. Adapun jika melihat data pada Global Islamic Finance Report (GIFR) tahun 2019, berdasarkan Islamic Finance Country Index (IFCI), Indonesia berada pada peringkat pertama dalam pasar keuangan syariah global.

Melihat peran strategis dan ketahanannya dalam menghadapi krisis membuat perkembangan perbankan syariah menjadi fenomena yang penting untuk dikaji lebih dalam. Perkembangan ini tentu tidak lepas dari konsep pembiayaan berkonsep syariah yang memiliki karakteristik berbeda dengan pembiayaan pada bank konvensional. Pembiayaan yang dimaksud adalah murabahah, musyarakah, dan ijarah.

Menindaklanjuti ketiga variabel tersebut, peneliti melakukan studi literatur perdana. Sebelumnya telah terdapat beberapa penelitian yang mengulas mengenai pengaruh pembiayaan murabahah, musyarakah, maupun ijarah terhadap profitabilitas perusahaan dan nilai perusahaan. Penelitian Raharjo \& Wahyuni (2019) menyimpulkan bahwa murabahah berpengaruh signifikan terhadap profitabilitas dan juga memiliki pengaruh signifikan terhadap nilai perusahaan. Penelitian Yusuf et al. (2019) menyatakan bahwa murabahah memiliki pengaruh positif signifikan namun musyarakah memiliki pengaruh positif tidak signifikan terhadap ROA. Hasil penelitian Putra (2018) menyatakan bahwa murabahah, musyarakah dan ijarah berpengaruh positif signifikan terhadap profitabilitas ROE. Adapun Sari \& Anshori (2017) menyatakan bahwa terhadap ROE, akad murabahah memiliki pengaruh signifikan negatif, dimana akad musyarakah tidak memiliki pengaruh signifikan.

Dari penelusuran yang telah dipaparkan sebelumnya, dapat dilihat masih terdapat ketidakkonsistenan hasil dari penelitian terdahulu. Selain itu, penelitian mengenai keterkaitan antara murabahah, musyarakah, ijarah, profitabilitas perusahaan dan nilai perusahaan belum pernah dilakukan dalam satu frame yang terpadu. Berdasarkan latar belakang tersebut, penulis tertarik untuk melakukan penelitian terkait pengaruh pembiayaan murabahah, musyarakah, dan ijarah pada kinerja perusahaan Bank Syariah.

Tujuan penelitian ini adalah untuk mengetahui pengaruh pembiayaan murabahah, musyarakah, dan ijarah terhadap profitabilitas dan nilai perusahaan. Penelitian diharapkan dapat dimanfaatkan oleh perusahaan sebagai bahan informasi dan pertimbangan dalam mengelola profitabilitas dengan memperhatikan transaksi pembiayaan murabahah, musyarakah, dan ijarah. Selain itu, dengan dasar tersebut, perusahaan mampu menjaga nilai perusahaan dalam dunia investasi. Penelitian juga diharapkan mampu menjadi bahan masukan dalam memberikan gambaran atas nilai perusahaan sebagai bahan pertimbangan bagi investor dalam keputusan investasi yang akan dilakukan. Terakhir, hasil dari penelitian ini diharapkan dapat menjadi bahan pertimbangan yang cukup bagi kreditur atas profitabilitas debitur, sehingga dapat ditentukan dengan tepat mengenai pengambilan keputusan pemberian pinjaman.

\section{Pengembangan Hipotesis}

Teori sinyal menunjukkan bahwa manajemen yang memiliki informasi mengenai kondisi perusahaan akan mengambil keputusan dimana hal ini akan memberikan sinyal informasi kepada pasar. Salah satu sinyal yang akan terus diusahakan oleh manajemen untuk ditunjukkan kepada pasar adalah kemampuan menghasilkan profitabilitas.
Sharia's Financing and Banking Performance

283 
Sharia's Financing and Banking Performance

\section{4}

Dalam transaksi murabahah, bank syariah memperoleh keuntungan atas selisih harga beli barang dengan harga yang disepakati oleh nasabah. Margin keuntungan ini akan dicatat dan dicantumkan sebagai penambah laba perusahaan. Karakteristik akad murabahah yang bersifat mengikat konsumen tanpa adanya pembatalan pesanan meminimalisir risiko kerugian perputaran persediaan. Hal ini sejalan dengan kesimpulan penelitian yang dilakukan oleh Yusuf et al. (2019) dimana dalam penelitian tersebut disimpulkan bahwa transaksi Murabahah memiliki pengaruh positif signifikan terhadap Profitabilitas Perusahaan Perbankan Syariah. Dengan demikian, hipotesis pertama dari penelitian ini adalah:

H1: Transaksi Pembiayaan Murabahah memiliki pengaruh positif terhadap profitabilitas perusahaan.

Signalling theory merupakan langkah yang dilakukan untuk menunjukkan kebijakan perusahaan. Dalam penggunaan sinyal, manajemen berusaha untuk menunjukkan pencapaian dan kepemilikan perusahaan, dimana tanpa adanya sinyal tersebut akan sulit untuk menyampaikan informasi kepada pihak luar tanpa ambiguitas. Untuk menunjukkan kemampuan mencapai target yang diharapkan, perusahaan menggunakan tingkat profitabilitas sebagai langkah mengeliminir ambiguitas. Transaksi musyarakah merupakan salah satu jenis pembiayaan yang ditawarkan oleh perbankan syariah dalam menjaring keuntungan. Pembiayaan ini biasanya digunakan oleh nasabah sebagai modal dalam menjalankan usaha. Keuntungan atas usaha kemudian dibagi kepada kedua belah pihak, nasabah selaku pemilik usaha dan bank syariah sebagai pihak yang membiayai. Keuntungan dan kerugian disalurkan atas dasar konsep bagi hasil dengan pembagian yang telah disepakati di awal. Penelitian yang dilakukan oleh Sari \& Anshari (2017) menunjukan bahwa terdapat pengaruh positif antara transaksi musyarakah terhadap profitabilitas perbankan syariah. Namun, penelitian ini tidak sejalan dengan penelitan yang dilakukan oleh Yusuf et al. (2019) dan penelitian yang dilakukan oleh Putra (2018) yang justru berkesimpulan bahwa Transaksi Musyarakah memiliki pengaruh negatif terhadap profitabilitas perusahaan perbankan syariah. Tidak dapat dipungkiri, pada transaksi pembiayaan musyarakah yang dilakukan oleh perbankan syariah melekat risiko kerugian. Risiko ini sejatinya bisa diminimalisir dengan pengamatan atas permohonan dan ketentuan berkas yang dilampirkan oleh nasabah. Dalam melaksanakan kegiatan operasional perusahaan, tentu perusahaan akan mempertimbangkan kegiatan mana yang berpotensi menghasilkan profit, termasuk dalam transaksi musyarakah. Oleh karena itu, hip[otesis kedua dalam penelitian ini adalah:

H2: Transaksi Pembiayaan Musyarakah memiliki pengaruh positif terhadap profitabilitas perusahaan.

Dalam teori sinyal, perusahaan yang bertindak sebagai pengirim sinyal akan memilih cara yang tepat untuk mengomunikasikan sinyal kepada pihak luar. Kondisi positif dalam perusahaan dapat dikomunikasikan kepada pasar dalam bentuk kemampuan menghasilkan profitabilitas. Keuntungan perusahaan dalam dunia perbankan tentunya sangat erat dengan transaksi pembiayaan. Transaksi ijarah adalah transaksi pembiayaan di mana bank syariah melakukan pembiayaan atas transaksi sewa barang yang dilakukan oleh nasabah. Transaksi ijarah dilaksanakan tanpa ada pemindahan kepemilikan atau terdapat pemindahan kepemilikan (Ijarah Muntahiya Bittamlik). Pemindahan kepemilikan ini dilakukan setelah terlebih dahulu disepakati oleh kedua belah pihak dan bersifat mengikat. Dalam penelitian yang dilakukan oleh Putra (2018) disimpulkan bahwa transaksi ijarah memiliki pengaruh positif signifikan terhadap profitabilitas perusahaan. Dikemukakan bahwa pendapatan sewa yang diterima perusahaan meningkatkan laba perusahaan. Dalam transaksi ijarah, pihak bank syariah dan nasabah menyetujui nilai harga sewa barang yang ditransaksikan. Nilai ini mencakup harga pokok barang dari pihak ketiga dan margin keuntungan untuk Bank. Margin keuntungan ini menjadi profit yang dicatat dalam laporan keuangan bank syariah. Sehingga hipotesis ketiga dalam penelitian ini adalah:

H3: Transaksi Pembiayaan Ijarah memiliki pengaruh positif terhadap profitabilitas perusahaan. 
Dalam signalling theory disebutkan bahwa manajemen akan berusaha untuk terus memberikan sinyal positif kepada investor. Salah satu bentuk sinyal positif tersebut adalah dengan membukukan profitabilitas yang tinggi. Transaksi Murabahah merupakan salah satu transaksi syariah yang memiliki peluang untuk menghasilkan profitabilitas tinggi dikarenakan adanya akad yang memberikan kepastian yang mengikat terjadinya transaksi penjualan. Dalam penelitian yang dilakukan oleh Raharjo \& Wahyuni (2019) disimpulkan bahwa Transaksi murabahah memiliki pengaruh positif signifikan terhadap nilai perusahan dengan profitabilitas sebagai variabel intervening. Namun, di sisi lain, penelitian tersebut juga menyimpulkan bahwa transaksi murabahah tidak memiliki pengaruh signifikan terhadap nilai perusahaan secara langsung.

Penelitian Tito \& Basuki (2014) menyimpulkan bahwa keputusan pendanaan berpengaruh positif dan signifikan terhadap nilai perusahaan. Salah satu bentuk pendanaan yang dilakukan oleh bank syariah adalah pembiayaan murabahah. Berdasarkan hal tersebut, hipotesis keempat dalam penelitian ini adalah:

H4: Transaksi Pembiayaan Murabahah memiliki pengaruh positifterhadap nilai perusahaan.

Hubungan antara transaksi musyarakah dan nilai perusahaan dapat dianalisa dengan menggunakan signalling theory. Transaksi musyarakah berpotensi menghasilkan profit bagi bank syariah. Kenaikan laba ini menjadi sinyal positif atas kinerja manajemen. Dalam teori sinyal, investor yang berperan sebagai penerima sinyal akan menanggapi informasi yang diberikan sesuai dengan interpretasinya masing-masing. Sinyal positif yang diterima oleh investor akan mengarah pada penilaian yang baik atas kondisi perusahaan. Penilaian ini akan mengarah pada pembelian saham oleh investor yang berkontribusi dalam peningkatan harga saham perusahaan. Sejauh ini belum ada penelitian yang membahas pengaruh antara transaksi musyarakah terhadap nilai perusahaan. Musyarakah yang merupakan salah satu bentuk dari keputusan pendanaan akan memberikan pengaruh positif dan signifikan terhadap nilai perusahaan, sehingga apabila keputusan pendanaan naik sebesar satu satuan, maka nilai perusahaan juga akan naik (Gustiandika \& Hadiprajitno, 2014). Dari pembahasan tersebut, hipotesis kelima dalam penelitian ini adalah:

H5: Transaksi Pembiayaan Musyarakah memiliki pengaruh positif terhadap nilai perusahaan.

Sinyal yang diberikan oleh manajemen dapat dimanfaatkan untuk mengurangi ketidakpastian dalam membuat keputusan yang disebabkan oleh ketidaklengkapan data dan asimetri informasi. Dengan memanfaatkan informasi ini, investor dapat dengan tepat mengetahui kinerja pasar perusahaan. Pengetahuan ini selanjutnya akan memberikan panduan dalam menentukan seberapa besar nilai suatu perusahaan. Sejauh ini belum ada penelitian yang membahas pengaruh antara transaksi ijarah terhadap nilai perusahaan. Transaksi ijarah yang dilakukan oleh perusahaan merupakan salah satu jenis dari kutusan pendanaan. Dengan demikian, peningkatan transaksi ijarah akan sejalan dengan peningkatan nilai perusahaan. Selain itu, konsep pembiayaan syariah yang menghindari riba juga memberikan efek lain berupa rasa aman bagi sebagian nasabah yang juga dapat mengarah pada kestabilan perusahaan. Kondisi ini dapat berkontribusi terhadap peningkatan harga saham. Dari paparan tersebut, hipotesis keenam dalam penelitian ini adalah:

H6: Transaksi Pembiayaan Ijarah memiliki pengaruh positif terhadap nilai perusahaan.

\section{METODE PENELITIAN}

Metode penelitian yang digunakan dalam penelitian ini adalah metode kuantitatif. Penelitian dengan metode ini dilakukan dengan cara mengumpulkan data kemudian Dalam penelitian ini, nilai perusahaan dipilih sebagai masalah utama dalam penelitian atau objek penelitian. Nilai perusahaan pada penelitian ini dicerminkan melalui Price Book Value (PBV). Penelitian ini menggunakan metode kuantitatif. Penelitian dilakukan dengan menggunakan studi deskriptif. Jenis data yang akan digunakan dalam penelitian ini adalah data sekunder. Data yang akan diolah merupakan data panel (pooled data). Populasi yang digunakan dalam penelitian ini adalah perusahaan keuangan dengan sektor perbankan, khususnya bank syariah. Sektor ini diambil karena perbankan syariah
Sharia's Financing and Banking Performance

285 
Sharia's Financing and Banking

Performance merupakan penggerak utama dari dunia keuangan syariah di Indonesia. Di samping itu, variabel yang akan diuji merupakan transaksi khusus yang hanya terjadi pada bank syariah. Berdasarkan populasi tersebut, langkah selanjutnya adalah penentuan sampel. Teknik pengambilan sampel yang akan digunakan adalah non-probability sampling. Penentuan sampel yang tidak acak mengharuskan adanya kriteria yang harus dipenuhi oleh suatu item dalam populasi. Terdapat tiga kriteria yang digunakan dalam penentuan sampel pada penelitian ini, yaitu sektor perusahaan perbankan yang menjalankan transaksi syariah, perusahaan telah terdaftar di Bursa Efek Indonesia, dan perusahaan memiliki laporan keuangan bulanan dari bulan Juli 2018 hingga Maret 2020. Berdasarkan kriteria tersebut, didapatkan empat perusahaan perbankan sebagai data cross section dengan data laporan keuangan sebagai data time series sebanyak 21 bulan, sehingga jumlah observasi dalam penelitian ini berjumlah 84 observasi.

Variabel penelitian ini terdiri dari profitabilitas yang menunjukkan kinerja operasi perusahaan dan nilai perusahaan yang menunjukkan kinerja pasar perusahaan. Profitabilitas menggunakan Return On Equity (ROE) sebagaimana yang digunakan oleh Sari \& Anshori (2018) yaitu sebagai berikut:

$$
R O E=\frac{\text { Pendapatan Bersih }}{\text { Jumlah rata }- \text { rata Ekuitas }}
$$

Nilai perusahaan menggunakan Price to Book Value (PBV) sebagaimana yang digunakan oleh Yulianto (2020), yaitu sebagai berikut:

$$
P B V=\frac{\text { Harga saham per lembar }}{\text { Nilai buku per lembar saham }}
$$

Terdapat tiga variabel independen dalam penelitian ini yaitu murabahah, musyarakah, dan ijarah. Pengukuran proksi murabahah dalam penelitian ini mengacu pada Faradila et al. (2017) menggunakan persamaan berikut:

$$
M R B=\frac{\text { Pembiayaan Murabahah }}{\text { Total Pembiayaan }}
$$

Pengukuran proksi musyarakah dalam penelitian ini mengacu pada Faradila et al. (2017) menggunakan persamaan berikut:

$$
M S R=\frac{\text { Pembiayaan Musyarakah }}{\text { Total Pembiayaan }}
$$

Proksi ijarah dalam penelitian ini sesuai dengan penelitian yang dilakukan oleh Faradila et al. (2017), yaitu menggunakan persamaan berikut:

$$
I J R=\frac{\text { Pembiayaan Ijarah }}{\text { Total Pembiayaan }}
$$

Dalam penelitian ini digunakan dua variabel kontrol, yaitu profitabilitas periode sebelumnya dan nilai perusahaan periode sebelumnya. Proksi profitabilitas yang digunakan pada penelitian ini adalah Return on Equity (ROE). Penggunaan profitabilitas (t-1) merupakan langkah yang dilakukan untuk mereduksi munculnya autokorelasi pada model penelitian pertama dan kedua. Persamaan yang digunakan dalam mengukur ROE adalah sebagai berikut:

$$
R O E_{(t-1)}=\frac{\text { Pendapatan } \operatorname{Bersih}_{(t-1)}}{\text { Jumlah rata }- \text { rata Ekuitas }(t-1)}
$$

Price to Book Value (PBV) merupakan proksi nilai perusahaan yang digunakan pada penelitian ini. PBV (t-1) digunakan sebagai variable kontrol untuk menurunkan tingkat autokorelasi pada model penelitian ketiga dan keempat. Persamaan dalam mengukur PBV adalah sebagai berikut:

$$
P B V_{(t-1)}=\frac{\text { Harga saham per lembar }}{(t-1)}
$$

Terbatasnya jumlah emiten yang menjadi data cross-section membuat tim penulis harus melakukan pemecahan model regresi menjadi dua persamaan. Untuk menemukan pengaruh variabel yang terdapat dalam hipotesis 1 hingga 3, digunakan model 1 dan 2 berikut: 


$$
\begin{aligned}
& R O E 1_{i t}=\alpha_{0}+\beta_{1} M R B_{i t}+\beta_{3} I J R_{i t}+\beta_{3} R O E_{i(t-1)}+\varepsilon_{i t} \\
& R O E 2_{i t}=\alpha_{0}+\beta_{1} M S R_{i t}+\beta_{2} I J R_{i t}+\beta_{3} R O E_{i(t-1)}+\varepsilon_{i t}
\end{aligned}
$$

Adapun hipotesis 4 hingga 6 menggunakan model 3 dan 4 berikut:

$$
\begin{aligned}
& P B V 1_{i t}=\alpha_{0}+\beta_{1} M R B_{i t}+\beta_{2} I J R_{i t}+\beta_{3} P B V_{i(t-1)}+\varepsilon_{i t} \\
& P B V 2_{i t}=\alpha_{0}+\beta_{1} M S R_{i t}+\beta_{2} I J R_{i t}+\beta_{3} P B V_{i(t-1)}+\varepsilon_{i t}
\end{aligned}
$$

Keterangan:

$$
\begin{array}{ll}
\text { ROEit } & =\text { profitabilitas perusahaan } \mathrm{i} \text { tahun } \mathrm{t} \\
\text { PBVit } & =\text { nilai perusahaan } \mathrm{i} \text { tahun } \mathrm{t} \\
\text { MRBit } & =\text { pembiayaan murabahah perusahaan } \mathrm{i} \text { tahun } \mathrm{t} \\
\text { MSRit } & =\text { pembiayaan musyarakah perusahaan } \mathrm{i} \text { tahun } \mathrm{t} \\
\text { IJRit } & =\text { pembiayaan ijarah perusahaan } \mathrm{i} \text { tahun } \mathrm{t} \\
\mathrm{ROEi}(\mathrm{t}-1) & =\text { profitabilitas perusahaan } \mathrm{i} \text { tahun } \mathrm{t}-1 \\
\mathrm{PBVi}(\mathrm{t}-1)=\text { nilai perusahaan } \mathrm{i} \text { tahun } \mathrm{t}-1 \\
\alpha 0=\text { konstanta } \\
\text { cit = error }
\end{array}
$$

\section{HASIL DAN PEMBAHASAN}

Hasil analisis statistik deksriptif untuk seluruh variabel yang digunakan dalam penelitian ini disajikan dalam Tabel 1.

Tabel 1. Statistik Deskriptif

\begin{tabular}{lccccccc}
\hline Keterangan & ROE & PBV & MRB & MSR & IJR & ROET1 & PBVT1 \\
\hline Mean & 0.0833 & 1.6716 & 0.4905 & 0.4674 & 0.0189 & 0.0846 & 1.7226 \\
Med. & 0.0253 & 0.7900 & 0.4441 & 0.4996 & $1.07 \mathrm{E}-05$ & 0.0275 & 0.8150 \\
Max. & 0.2690 & 6.8600 & 0.9999 & 0.9363 & 0.0788 & 0.2972 & 6.8600 \\
Min. & 0.0061 & 0.1300 & 0.0347 & 0.0000 & 0.0000 & 0.0061 & 0.2100 \\
Std. Dev. & 0.1032 & 1.8514 & 0.3418 & 0.3337 & 0.0291 & 0.1036 & 1.8683 \\
\hline
\end{tabular}

Sumber: data diolah

Pengujian hipotesis dengan model 1 dan 2 dilakukan dengan fixed effect model terdapat adalam Tabel 2 dan Tabel 3.

Tabel 2. Hasil Uji-t model regresi ROE1

\begin{tabular}{lllll}
\hline Variable & Coeff. & t-Stat & Prob. & \\
\hline C & 0.0035 & 0.4388 & 0.3310 & \\
MRB & 0.0226 & 1.6048 & 0.0563 & $*$ \\
IJR & 0.0770 & 1.1152 & 0.1341 & \\
ROET1 & 0.7936 & 13.6301 & 0.0000 & $* * *$ \\
R2 & 0.9955 & & & \\
Adj. R2 & 0.9951 & & & \\
F-stat. & 2830.13 & & & \\
Prob(F-stat.) & 0.0000 & & & \\
\hline *** Signifikansi 99\%, ** Signifikansi 95\%, * Signifikansi $90 \%$ & &
\end{tabular}

Sumber: data diolah

Tabel 3. Hasil Uji-t model regresi ROE2

\begin{tabular}{lllll}
\hline Variable & Coeff. & t-Stat & Prob. & \\
\hline C & 0.0246 & 2.9739 & 0.0039 & $* * *$ \\
MSR & -0.0198 & -1.6420 & 0.0524 & $*$ \\
IJR & 0.0412 & 0.6602 & 0.5111 & \\
ROET1 & 0.7938 & 13.8138 & 0.0000 & $* * *$ \\
R2 & 0.9956 & & & \\
Adj. R2 & 0.9953 & & & \\
F-stat. & 2968.49 & & & \\
Prob(F-stat.) & 0.0000 & & & \\
\hline *** Signifikansi 99\%, ** Signifikansi 95\%, * Signifikansi 90\% & \\
\hline
\end{tabular}

Sumber: data diolah 
Sharia's Financing and Banking Performance
Selanjutnya pengujian hipotesis dengan model 3 dan 4 dilakukan dengan common effect model terdapat dalam Tabel 4 dan Tabel 5.

Tabel 4. Hasil Uji-t model regresi PBV1

\begin{tabular}{lllll}
\hline Variable & Coeff. & t-Stat. & Prob. & \\
\hline C & 0.0541 & 1.7735 & 0.0399 & $* *$ \\
MRB & -0.0091 & -0.0904 & 0.4641 & \\
IJR & -1.9532 & -1.8048 & 0.0375 & $* *$ \\
PBVT1 & 0.9287 & 29.3898 & 0.0000 & $* * *$ \\
R2 & 0.9196 & & & \\
Adj. R2 & 0.9165 & & & \\
F-stat. & 305.05 & & & \\
Prob(F-stat.) & 0.0000 & & & \\
\hline *** Signifikansi 99\%, ** Signifikansi $95 \%,{ }^{*}$ Signifikansi $90 \%$ & \\
\hline
\end{tabular}

Sumber: data diolah

Tabel 5. Hasil Uji-t model regresi PBV2

\begin{tabular}{|c|c|c|c|c|}
\hline Variable & Coeff. & t-Stat. & Prob. & \\
\hline $\mathrm{C}$ & 0.0450 & 0.5119 & 0.3050 & \\
\hline MSR & 0.0094 & 0.0927 & 0.4632 & \\
\hline IJR & -1.9454 & -1.7100 & 0.0455 & $* *$ \\
\hline PBVT1 & 0.9289 & 29.4481 & 0.0000 & $* * *$ \\
\hline $\mathrm{R} 2$ & 0.9196 & & & \\
\hline Adj. R2 & 0.9166 & & & \\
\hline F-stat. & 305.10 & & & \\
\hline Prob(F-stat.) & 0.0000 & & & \\
\hline
\end{tabular}

Sumber: data diolah

\section{Pengaruh Murabahah terhadap Profitabilitas Perusahaan}

Hasil penelitian mengindikasikan bahwa transaksi murabahah memiliki pengaruh positif terhadap profitabilitas perusahaan. Transaksi Murabahah memegang peranan penting dimana bank syariah memperoleh keuntungan atas selisih harga barang dengan harga yang disepakati nasabah. Margin keuntungan ini akan dicatat dan dicantumkan sebagai penambah laba perusahaan. Karakteristik akad murabahah yang bersifat mengikat konsumen tanpa adanya pembatalan pesanan meminimalisir risiko kerugian perputaran persediaan. Berkurangnya risiko kerugian ini memberi pengaruh terhadap tingkat profitabilitas perusahaan. Dari data yang diolah, diketahui bahwa transaksi Murabahah memiliki proporsi yang cukup tinggi dibandingkan dengan transaksi pembiayaan lain. Posisi pembiayaan murabahah rata-rata menopang $49 \%$ pembiayaan perusahaan dengan proporsi tertinggi sebesar $99 \%$. Hal ini memberikan gambaran bahwa manajemen cenderung memilih opsi pembiayaan murabahah yang cenderung berpengaruh positif terhadap profitabilitas.

Yusuf et al. (2019) menyimpulkan bahwa transaksi Murabahah memiliki pengaruh positif signifikan terhadap Profitabilitas Perusahaan Perbankan Syariah. Kesimpulan tersebut sejalan dengan pengujian yang dilakukan oleh peneliti. Pengaruh positif ini diduga tidak terlepas dari sifat transaksi pembiayaan murabahah yang beresiko rendah karena adanya ketentuan yang bersifat mengikat konsumen yang melakukan pembiayaan murabahah.

Dalam kaitannya dengan teori sinyal, teori ini menunjukkan bahwa manajemen yang memiliki informasi mengenai kondisi perusahaan akan mengambil keputusan dimana hal ini akan memberikan sinyal informasi kepada pasar. Salah satu sinyal yang akan terus diusahakan oleh manajemen untuk ditunjukkan kepada pasar adalah kemampuan menghasilkan profitabilitas. Pembiayaan murabahah yang dijalankan oleh bank syariah merupakan salah satu sinyal positif yang dikirimkan oleh manajemen perusahaan.

Pengaruh MUSYARAKAH terhadap Profitabilitas Perusahaan 
Hasil penelitian menunjukkan bahwa transaksi pembiayaan musyarakah memiliki pengaruh negatif terhadap profitabilitas perusahaan. Transaksi pembiayaan musyarakah merupakan transaksi pembiayaan lain yang memiliki volume cukup besar dari data yang diuji. Proporsi transaksi musyarakah terhadap total pembiayaan mencapai nilai maksimal $93 \%$ dengan rata-rata sebesar $46 \%$. Dengan proporsi kontribusi yang cukup tinggi, wajar jika hasil pengujian menunjukan adanya pengaruh signifikan antara transaksi musyarakah dengan profitabilitas perusahaan.

Pengaruh negatif transaksi musyarakah terhadap profitabilitas perusahaan dapat dijabarkan dengan memahami konteks pembiayaan musyarakah. Dalam transaksi pembiayaan musyarakah, terdapat risiko kerugian yang terjadi apabila pembiayaan usaha yang diberikan oleh pihak bank kepada nasabah tidak menuai hasil. Kerugian tersebut ditanggung oleh kedua belah pihak, baik pihak bank maupun nasabah. Adanya risiko pembiayaan ini menjadi penyebab korelasi negatif antara pembiayaan musyarakah dan profitabilitas perusahaan.

Hasil penelitian ini sejalan dengan penelitian yang dilakukan oleh Yusuf et al. (2019) dan Putra (2018) yang memberikan kesimpulan bahwa transaksi musyarakah memiliki pengaruh negatif terhadap profitabilitas perusahaan. Adanya resiko ketidakpastian pembayaran diduga menjadi penyebab pengaruh negatif transaksi musyarakah terhadap profitabilitas perusahaan.

Terkait Signalling Theory, teori ini dapat dijabarkan sebagai langkah yang dilakukan untuk menunjukkan kebijakan perusahaan. Profitabilitas adalah salah satu bentuk sinyal yang disampaikan oleh manajemen perusahaan. Meski demikian, ada kalanya sinyal yang dikirimkan oleh manajemen perusahaan tidak sesuai dengan harapan perusahaan. Hal ini salah satunya ditunjukkan dalam penyampaian informasi mengenai transaksi pembiayaan musyarakah yang dilakukan oleh perusahaan.

\section{Pengaruh IJARAH terhadap Profitabilitas Perusahaan}

Hasil pengujian menunjukkan bahwa transaksi pembiayaan ijarah tidak memiliki pengaruh terhadap profitabilitas perusahaan. Transaksi ijarah merupakan salah satu transaksi pembiayaan yang dilakukan oleh perusahaan perbankan syariah. Dari data yang dikumpulkan, diketahui bahwa transaksi pembiayaan ini tidak sepopuler transaksi pembiayaan lainnya. Terdapat beberapa data dimana perusahaan sama sekali tidak memiliki transaksi pembiayaan Ijarah dalam neraca perusahaan. Proporsi pembiayaan Ijarah terhadap keseluruhan pembiayaan secara rata-rata adalah sebesar 1,8\% dengan nilai terbesar adalah 7,8\%. Proporsi yang cenderung kecil terkait erat dengan hasil pengujian yang menunjukan tidak adanya pengaruh variabel transaksi ijarah terhadap profitabilitas perusahaan. Hasil pengujian ini sejalan dengan penelitian yang dilakukan oleh Faradila et al. (2017) yang menyatakan bahwa ijarah tidak berpengaruh terhadap profitabilitas.

Transaksi ijarah adalah transaksi pembiayaan di mana bank syariah melakukan pembiayaan atas transaksi persewaan barang yang dilakukan oleh nasabah. Transaksi ini dilaksanakan tanpa adanya pemindahan kepemilikan atau terdapat pemindahan kepemilikan (Ijarah Muntahiya Bittamlik). Pemindahan kepemilikan ini dilakukan setelah terlebih dahulu disepakati oleh kedua belah pihak dan bersifat mengikat. Dalam proses bisnis perbankan konvensional, transaksi ijarah dapat dipersamakan dengan transaksi pembiayaan leasing. Hanya saja terdapat perbedaan perlakuan dalam hal perpajakan pada kedua transaksi tersebut, di mana atas transaksi Ijarah terdapat isu pajak berganda. Adanya ketimpangan ini diperkirakan menyebabkan transaksi pembiayaan ijarah kalah populer dibanding transaksi leasing pada perbankan konvensional dan berdampak pada rendahnya transaksi ijarah pada bank syariah yang mengakibatkan transaksi pembiayaan ini tidak berpengaruh pada profitabilitas perusahaan.

Dalam teori sinyal, perusahaan yang bertindak sebagai pengirim sinyal akan memilih cara yang tepat untuk mengomunikasikan sinyal kepada pihak luar. Salah satu bentuk komunikasi sinyal yang dikirimkan adalah profitabilitas. Ijarah sebagai salah satu transaksi pembiayaan yang dilakukan perusahaan perbankan syariah tentu diekspektasikan dapat menghasilkan profitabilitas. Meski demikian, rendahnya minat
Sharia's Financing and Banking Performance

289 
Sharia's Financing and Banking Performance masyarakat atas jenis pembiayaan ini membuat hasil yang didapat tidak sesuai dengan ekspektasi manajemen.

\section{Pengaruh MURABAHAH terhadap NILAI Perusahaan}

Hasil pengujian mengindikasikan bahwa transaksi murabahah tidak memiliki pengaruh terhadap nilai perusahaan. Terkait transaksi murabahah yang disalurkan oleh bank syariah, pasar tidak memberikan respon atas kenaikan maupun penurunan pada jenis pembiayaan tersebut. Jika melihat data pada seluruh sampel yang digunakan, pembiayaan murabahah adalah transaksi yang paling mendominasi dalam siklus keuangan pada bank syariah. Hampir lima puluh persen dari seluruh transaksi pembiayaan di bank syariah berbentuk murabahah. Meski begitu, kondisi ini ternyata tidak menjadi bahan pertimbangan bagi pasar, dalam hal ini para investor, dalam menentukan harga saham emiten terkait.

Murabahah sendiri merupakan suatu transaksi keuangan berupa jual beli aset dari pihak bank kepada nasabah dengan batasan profit yang telah ditentukan. Transaksi ini bukan merupakan hal yang hanya terdapat pada pembiayaan bank syariah sehingga bukan merupakan suatu hal yang unik dan inovatif. Murabahah layaknya pembiayaan kredit pada bank konvensional yang bertujuan membantu debitur untuk memiliki suatu aset tertentu. Murabahah memiliki kelebihan dimana cicilan yang akan dibayarkan oleh debitur berjumlah tetap dalam setiap periode dengan tanpa adanya denda keterlambatan. Meski begitu, dalam banyak kasus, murabahah memiliki total biaya yang lebih tinggi dari pembiayaan kredit konvensional. Oleh karena itu, pembiayaan kredit konvensional masih lebih populer di kalangan masyarakat Indonesia.

Raharjo \& Wahyuni (2019) menyatakan bahwa murabahah memiliki pengaruh terhadap nilai perusahaan dengan probabilitas sebagai variabel intervening. Meski begitu, dalam penelitian tersebut juga disebutkan bahwa murabahah tidak memiliki pengaruh terhadap nilai perusahaan. Penelitian tersebut sejalan dengan hasil yang didapat dari penelitian ini. Berdasarkan berbagai hal yang telah disebutkan sebelumnya, murabahah yang tidak memiliki pengaruh terhadap nilai perusahaan kemungkinan disebabkan oleh keyakinan investor bahwa murabahah bukanlah suatu produk pembiayaan yang inovatif dan bukan merupakan transaksi perbankan yang populer di Indonesia.

Dalam teori sinyal, perusahaan akan memberikan sinyal atas kegiatan operasi kepada pasar. Sebagai hasil dari pemberian sinyal tersebut, pasar akan memberikan respon yang beragam. Respon yang diharapkan oleh perusahaan tentunya adalah respon yang positif. Namun, suatu tindakan positif yang dilakukan perusahaan belum tentu akan mendapatkan respon yang senada. Hal ini adalah yang terjadi pada transaksi pembiayaan murabahah, dimana pasar dapat tidak bereaksi atas sinyal tersebut, bahkan kadang justru memberikan respon yang negatif.

\section{Pengaruh MUSYARAKAH terhadap NILAI Perusahaan}

Hasil pengujian menunjukkan bahwa transaksi musyarakah tidak memiliki pengaruh terhadap nilai perusahaan. Musyarakah adalah akad pendanaan syariah yang dilakukan oleh dua pihak atau lebih dengan tujuan menjalankan suatu kegiatan usaha atas modal bersama. Keuntungan maupun kerugian yang dialami oleh usaha bersama tersebut akan ditanggung secara proporsional oleh masing-masing pihak sesuai ketentuan yang telah disepakati di awal masa kongsi. Jenis pembiayaan seperti ini tidak terdapat pada bank konvensional. Hal ini membuat pembiayaan musyarakah menjadi suatu opsi yang inovatif dan unik bagi bank syariah. Namun, penyaluran pendanaan ini memiliki karakteristik tersendiri, dimana pihak yang diberikan opsi pembiayaan musyarakah pada umumnya memiliki prospek usaha yang kurang menjanjikan dengan kondisi kestabilan usaha yang belum mapan. Kondisi ini mereduksi prinsip kehati-hatian yang dijalankan oleh perbankan dalam penyaluran kredit (prudential banking).

Kedua kondisi yang saling bertentangan tersebut, dimana musyarakah merupakan suatu terobosan pembiayaan yang inovatif memiliki kontribusi positif terhadap pandangan investor sedangkan di sisi lain pembiayaan musyarakah mereduksi prudential banking yang memunculkan sentimen negatif dari pasar, diperkirakan menjadi penyebab pasar tidak memberikan respon atas sinyal perusahaan yang berbentuk transaksi 
musyarakah, Oleh sebab itu, transaksi musyarakah tidak memiliki pengaruh terhadap nilai perusahaan.

Teori sinyal menyebutkan bahwa sinyal yang dikirimkan dapat memiliki informasi yang berbeda. Perusahaan dapat mengirimkan sinyal positif maupun negatif kepada pihak lain. Sinyal tersebut akan diserap oleh pihak penerima untuk selanjutnya diterjemahkan dalam penafsiran masing-masing. Pengiriman sinyal mengenai keberhasilan maupun kegagalan yang dialami perusahaan didorong oleh adanya asimetri informasi, dimana investor hanya memiliki sebagian kecil informasi dibandingkan dengan informasi yang beredar di kalangan manajemen perusahaan.

Adanya asimetri informasi ini membuat perbedaan penafsiran antara investor dan manajemen perusahaan dapat mengemuka. Dalam hal ini adalah asimetri informasi mengenai transaksi musyarakah. Bagi perusahaan, transaksi musyarakah memiliki porsi yang besar dalam pembiayaan kepada nasabah. Secara rata-rata, transaksi ini memiliki peranan sebesar $46,74 \%$ dari seluruh porsi pembiayaan yang disalurkan oleh bank syariah, nilai yang hampir sama dengan transaksi murabahah. Meski demikian, besarnya pembiayaan musyarakah ternyata tidak menjadi pertimbangan bagi pasar dalam menentukan harga saham perusahaan.

\section{Pengaruh IJARAH terhadap NILAI Perusahaan}

Hasil penelitian menunjukkan bahwa transaksi pembiayaan ijarah memiliki pengaruh negatif terhadap nilai perusahaan. Ijarah merupakan suatu transaksi sewa aset yang dimiliki bank oleh nasabah selama periode yang telah ditentukan. Pada akhir masa sewa, aset tersebut akan dijual kepada nasabah sehingga baik hak guna maupun hak milik akan berpindah dari bank kepada nasabah. Kontrak atas sewa dan penjualan di akhir masa sewa telah ditentukan di awal periode sewa oleh kedua belah pihak. Dari definisi tersebut, ijarah memiliki kemiripan dengan transaksi leasing yang umum digunakan pada bank konvensional. Melihat hal tersebut, dapat dikatakan bahwa ijarah bukan merupakan suatu jenis pembiayaan yang inovatif, melainkan hanya transaksi leasing yang diserahkan dengan akad syariah.

Apabila dipahami lebih lanjut, transaksi pembiayaan melalui ijarah merupakan dua transaksi yang berbeda. Pertama adalah transaksi jual beli aset antara supplier dengan pihak bank. Transaksi ini, dalam ketentuan perpajakan, merupakan suatu transaksi penyerahan yang dikenai Pajak Pertambahan Nilai (PPN). Transaksi kedua adalah transaksi sewa antara pihak bank dengan nasabah. Pada siklus ini, seperti transaksi penjualan sebelumnya, juga dikenai Pajak Pertambahan Nilai atas jasa sewa. Oleh karenanya, transaksi ijarah mengalami dua kali pengenaan Pajak Pertambahan Nilai yang seluruhnya akan ditanggung oleh nasabah. Pengenaan pajak berganda ini membuat biaya yang harus dikeluarkan nasabah atas transaksi ijarah lebih besar jika dibandingkan dengan pembiayaan leasing pada bank konvensional. Keadaan ini mengarah pada kurang diminatinya pembiayaan ijarah di kalangan masyarakat.

Tim peneliti memperkirakan bahwa sebagai respon atas kondisi yang tidak menguntungkan tersebut, pasar memberikan respon negatif atas pembiayaan ijarah. Oleh karena itu, transaksi ijarah memiliki pengaruh negatif atas nilai suatu perusahaan.

Mengacu pada signaling theory, pemanfaatan atas sinyal yang diberikan oleh manajemen dapat mengurangi ketidakpastian dalam membuat keputusan yang disebabkan oleh ketidaklengkapan data dan asimetri informasi (Bergh et al., 2014). Meski demikian, manajemen akan berusaha untuk terus memberikan sinyal positif kepada investor dengan membukukan keuntungan yang positif sehingga berimbas pada kenaikan nilai perusahaan. Agar dapat memahami kondisi perusahaan yang sebenarnya, investor perlu melakukan analisis atas berbagai sinyal yang dikirimkan oleh pihak manajemen.

Salah satu sinyal yang akan dianalisis oleh investor adalah pembiayaan ijarah. Jika melihat data, porsi transaksi ijarah terhadap total pembiayaan yang disalurkan oleh perusahaan sangat kecil, tidak mencapai angka dua persen. Jumlah maksimum penyaluran dana melalui transaksi ijarah bahkan hanya di kisaran 7,88\%. Namun, kontribusi yang kecil tersebut ternyata membawa pengaruh besar bagi para investor.
Sharia's Financing and Banking Performance

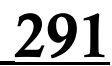


Sharia's Financing and Banking Performance

\section{2}

Dimana keberadaan pembiayaan ijarah mengarah pada sentiment negatif atas harga saham suatu bank syariah.

\section{PENUTUP}

Penelitian ini menyimpulkan bahwa transaksi murabahah berpengaruh positif terhadap profitabilitas pada bank syariah. Murabahah memegang peranan penting dalam perolehan keuntungan bank syariah yang diperoleh atas selisih harga barang dengan harga yang disepakati nasabah. Pembiayaan musyarakah berpengaruh negatif terhadap profitabilitas pada bank syariah. Jenis pembiayaan ini membagi keuntungan dan kerugian yang dialami oleh pihak rekanan usaha kepada kedua pihak, bank syariah dan pihak peminjam dana. Kerugian yang dialami rekanan juga harus ditanggung oleh pihak bank yang mengakibatkan jenis pembiayaan ini memiliki pengaruh negatif terhadap profitabilitas perusahaan. Transaksi ijarah tidak memiliki pengaruh terhadap profitabilitas pada bank syariah. Transaksi ijarah dapat dipersamakan dengan transaksi pembiayaan leasing yang dilakukan oleh bank konvensional.

Selanjutnya, transaksi murabahah tidak memiliki pengaruh terhadap nilai perusahaan pada perbankan syariah. Proses bisnis murahabahah cenderung sama dengan pembiayaan kredit bank konvensional membuat jenis transaksi ini bukan pembiayaan yang inovatif. Oleh karena itu, investor yang tidak mempertimbangkan besarnya transaksi murabahah pada bank syariah sebagai salah satu faktor dalam menentukan harga saham. Pembiayaan musyarakah tidak memiliki pengaruh terhadap nilai perusahaan pada sektor perbankan syariah. Berbeda dengan murabahah, pembiayaan musyarakah adalah model pembiayaan yang tidak terdapat pada bank konvensional. Transaksi ijarah yang berpengaruh negatif terhadap nilai perusahaan sektor perbankan syariah. Ijarah merupakan transaksi pembiayaan yang serupa dengan leasing pada bank konvensional. Namun, sebagai konsekuensi atas proses bisnis yang disesuaikan dengan ketentuan syariah, transaksi ijarah menanggung beban yang lebih besar dengan adanya pajak berganda terkait Pajak Pertambahan Nilai (PPN). Akibat dari timbulnya pajak berganda ini adalah rendahnya tingkat popularitas ijarah dalam porsi pembiayaan pada bank syariah.

\section{DAFTAR PUSTAKA}

[1] Ali, M. S., \& Al-Azhari, A. W. J. (2020). Incongruity in Contemporary and Shariah Compliant Current Accounts and Ijarah Operated by Islamic Banking. Al-Idah, $37(2), 1-10$.

[2] Anita, W. F., Nawawi, A., \& Putri, D. (2020). Pengaruh Pembiayaan Mudharabah dan Pembiayaan Musyarakah terhadap Tingkat Profitabilitas pada Bank Syariah (Studi pada Bank Syariah yang Terdaftar di BI Periode 2015-2017). Accounthink: Journal of Accounting and Finance, 5(1).

[3] Bashir, A. H. M. (1999). Risk and profitability measures in Islamic banks: The case of two Sudanese banks. Islamic Economic Studies, 6(2).

[4] Bergh, D. D., Connelly, B. L., Ketchen Jr, D. J., \& Shannon, L. M. (2014). Signalling theory and equilibrium in strategic management research: An assessment and a research agenda. Journal of Management Studies, 51(8), 1334-1360.

[5] Christiawan, Y. J., \& Tarigan, J. (2007). Kepemilikan manajerial: kebijakan hutang, kinerja dan nilai perusahaan. Jurnal Akuntansi dan Keuangan, 9(1), 1-8.

[6] Clark, J. M., Cornwell, T. B., \& Pruitt, S. W. (2002). Corporate stadium sponsorships, signalling theory, agency conflicts and shareholder wealth. Journal of Advertising Research, 42(6), 16-32.

[7] CNN Indonesia. 2019. Penyebaran Stagnan, RI Peringkat 1 Keuangan Syariah Global. https://www.cnnindonesia.com/ekonomi/20191018122546-78440645/penyebaran-stagnan-ri-peringkat-1-keuangan-syariah-global (akses pada 1 Mei 2020). 
[8] Connelly, B. L., Certo, S. T., Ireland, R. D., \& Reutzel, C. R. (2011). Signaling theory: A review and assessment. Journal of management, 37(1), 39-67.

[9] Daryanto, S.M., Fahmi, M. and Djanegara, M.S., 2020. Impact of DAPODIK Information Quality on Optimization of Education Budget Decision Making from User Perspective. Journal of Talent Development and Excellence, 12(3s), pp.2811-2828.

[10] Djanegara, M.S., Mulyani, S., Putra, D.M., Zahra, N.A.K. and Mauludina, M.A., 2018. The effect of institutionalization isomorphic pressures and the role of knowledge management on investment decisions of the accounting information systems. Polish Journal of Management Studies, 18.

[11] Eprianti, N., \& Adhita, O. (2017). Pengaruh Pendapatan Ijarah Terhadap Profitabilitas. Amwaluna: Jurnal Ekonomi Dan Keuangan Syariah, 1(1), 19-33.

[12] Faradilla, C., Arfan, M., \& Shabri, M. (2017). Pengaruh pembiayaan murabahah, istishna, ijarah, mudharabah dan musyarakah terhadap profitabilitas bank umum syariah di Indonesia. Jurnal Administrasi Akuntansi: Program Pascasarjana Unsyiah, 6(3).

[13] Gustiandika, T., \& Hadiprajitno, P. B. (2014). Pengaruh keputusan investasi dan keputusan pendanaan terhadap nilai perusahaan dengan corporate governance sebagai variabel moderating. Diponegoro Journal Of Accounting, 3(2), 1141-1152.

[14] Hermuningsih, S. (2014). Pengaruh Profitabilitas, Growth Opportunity, Struktur Modal Terhadap Nilai Perusahaan Pada Perusahaan Publik di Indonesia. Buletin Ekonomi Moneter Dan Perbankan, 16(2), 127-148.

[15] Iriyadi, I., Maulana, M.A. and Nurjanah, Y., 2018, December. Financial Reporting for Micro Small and Medium Enterprises Towards Industrial Revolution Era 4.0. In International Conference On Accounting And Management Science 2018 (pp. 32-38).

[16] Kartini, Dupla. 2016. Perbankan dalam pusaran krisis moneter 1997-1998. https://lipsus.kontan.co.id/v2/perbankan/read/320/perbankan-dalam-pusarankrisis-moneter (akses pada 30 April 2020).

[17] Kembauw, E., Munawar, A., Purwanto, M.R., Budiasih, Y. and Utami, Y., 2020. Strategies of Financial Management Quality Control in Business. Manfacturers' Capital Structure.

[18] Kothari, C. R. (2004). Research Methodology: Methods and Techniques (Second Edi). New Age International Ltd.

[19] Lita, R. P., Meuthia, M., \& Ma'ruf, M. (2019). Model Keterkaitan Inovasi Pemasaran, Kinerja Pasar, dan Kinerja Keuangan pada Usaha Oleh-Oleh di Sumatera Barat. Bilancia: Jurnal Ilmiah Akuntansi, 3(3), 276-286.

[20] Mas'ud, I., Setiawan, E., \& Yuliarti, N. C. (2020). The Effect of Financing Trading, Profit Sharing and Ijarah to Falah in Sharia Banks. Journal of Contemporary Information Technology, Management, and Accounting, 1(1), 39-46.

[21] Ningsih, A. S., \& Kusumawati, Y. T. (2020). Pengaruh Pertumbuhan Penjualan Terhadap Profitabilitas Perusahaan Food And Beverages Yang Terdaftar Di Bursa Efek Indonesia Periode 2013-2017. Borneo Student Research (BSR), 1(2), 877-882.

[22] Nofrita, R. (2013). Pengaruh Profitabilitas terhadap Nilai Perusahaan dengan Kebijakan Deviden sebagai Variabel Intervening (Studi Empiris pada Perusahaan Manufaktur yang Terdaftar di BEI). Jurnal Akuntansi, 1(1).

[23] Nor, A. M., Ibrahim, S. N., \& Daud, S. (2020). Recovery Issues on Murabahah Financing in Malaysia. International Journal of Academic Research in Business and Social Science, 10(4), 295-308.

[24] Pamungkas, B., Flassy, D.A., Yudanto, S., Rachman, H.A., Rahayu, S., Komarudin, S. and Setijono, H., 2018. Accrual-based accounting implementation in Indonesian's local governments compared to other countries' experiences. Man in India, 98(1), pp.1-23.

[25] Perwitasari, M. P., \& Suwarno, A. E. (2020). Pengaruh Ukuran Perusahaan, Leverage, Dan Investment Opportunity Set Terhadap Nilai Perusahaan (Studi 
Sharia's Financing and Banking Performance

\section{4}

Empiris Pada Perusahaan Manufaktur yang Terdaftar Di BEI Periode Tahun 20152017) (Doctoral dissertation, Universitas Muhammadiyah Surakarta).

[26] Purba, J.H.V. and Septian, M.R., 2019. Analysis of Short Term Financial Performance: A Case Study of an Energy Service Provider. Journal of Accounting Research, Organization and Economics, 2(2), pp.113-122.

[27] Putra, P., \& Hasanah, M. (2018). Pengaruh pembiayaan mudharabah, musyarakah, murabahah, dan ijarah terhadap profitabilitas 4 bank umum syariah periode 2013-2016. Jurnal Organisasi dan Manajemen, 14(2), 140-150.

[28] Raharjo, S., \& Wahyuni, S. (2019). Analisis Pengaruh Pembiayaan Murabahah Dan Mudharabah Terhadap Nilai Perusahaan Dengan Profitabilitas Sebagai Variabel Intervening. Jurnal Bisnis dan Manajemen (Journal of Business and Management), 19(1), 39-50.

[29] Ross, S. A. (1977). The determination of financial structure: the incentive-signalling approach. The bell journal of economics, 23-40.

[30] Saleem, S., \& Mansor, F. (2020). Exploring Compliance of AAOIFI Shariah Standard on Ijarah Financing: Analysis on the Practices of Islamic Banks in Malaysia. Journal of Risk and Financial Management, 13(2), 29.

[31] Sari, D. W., \& Anshori, M. Y. (2018). Pengaruh Pembiayaan Murabahah, Istishna, Mudharabah, Dan Musyarakah Terhadap Profitabilitas (Studi Pada Bank Syariah Di Indonesia Periode Maret 2015 - Agustus 2016). Accounting and Management Journal, 1(1).

[32] Yulianto, W. (2020). Analisis Faktor-Faktor Yang Mempengaruhi Nilai Perusahaan. Jurnal Multiparadigma Akuntansi, 2(2), 576-585.

[33] Yusuf, D., \& Kholik, K. (2019). The Effect of Buy and Sell Financing (Murabahah), Profit Share Financing (Mudarabah), Equity Capital Financing (Musyarakah) and Non-Performing Financing Ratio on Profitability Level of Sharia Commercial Banks in North Sumatera. Britain International of Humanities and Social Sciences (BIoHS) Journal, 1(1), 81-88. 